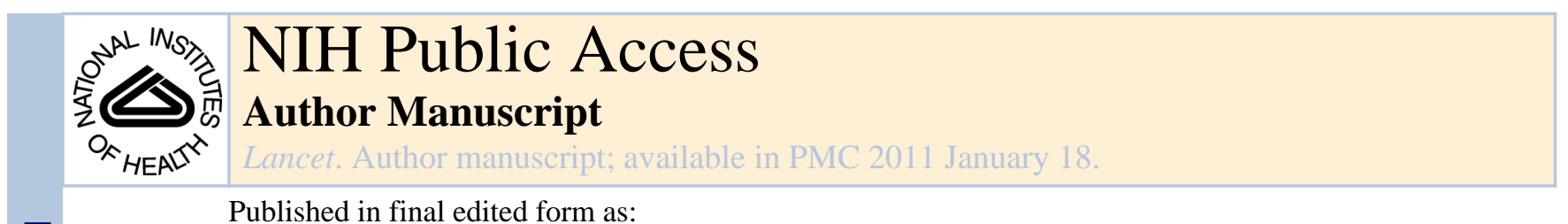

Published in final edited form as:

Lancet. 1983 May 14; 1(8333): 1073-1075.

\title{
LIVER TRANSPLANTATION FOR TYPE I GLYCOGEN STORAGE DISEASE
}

\author{
J. Jeffrey Malatack, David N. Finegold, Shunzaburo Iwatsuki, Byers W. Shaw Jr, J. Carlton \\ Gartner, Basil J. Zitelli, Thomas Roe, and Thomas E. Starzl \\ Departments of Pediatrics and Surgery, University Health Center of Pittsburgh, Pittsburgh \\ Pennsylvania 15261, USA; and Department of Pediatrics, University of Southern California
}

\section{Summary}

A 161/2-year-old girl with type I glycogen storage disease was treated by orthotopic liver transplantation under cyclosporin/steroid immunosuppression. All metabolic stigmata of the disease were relieved and 1 year postoperatively she follows a normal diet and lifestyle.

\section{Introduction}

Studies of haptoglobin, ${ }^{1-3}$ group-specific component, ${ }^{3,4}$ and numerous other products of hepatic synthesis ${ }^{5-9}$ have shown that liver homografts permanently retain their original metabolic specificity after transplantation. Consequently, liver transplantation has been regarded for some years ${ }^{4}$ as a potentially decisive way to treat those inborn errors of metabolism which result partly or completely from defects in hepatic function. This objective has been realised in several different metabolic disorders. ${ }^{8,9} \mathrm{We}$ report here the first use of liver transplantation for the treatment of type I glycogen storage disease, a disorder caused by giucose-6-phosphatase deficiency.

\section{Case-report}

The patient was a girl aged $161 / 2 \mathrm{yr}$ whose sibling had died in infancy of the same disease. At age $2 \frac{1}{2} \mathrm{yr}$ she had had a prolonged hypoglycaemic seizure which resulted in transient blindness, hemiparesis, and a residual seizure disorder requiring therapy with anticonvulsants. She continued to have recurrent hypoglycaemia, acidosis, hyperuricaemia, hyperlipidaemia, abnormal coagulation, and epistaxes, and her growth was retarded. After an end-to-side portacaval shunt at age $8 \mathrm{yr},{ }^{10}$ all these abnormalities were relieved except hypoglycaemia. The frequency of feedings necessary to avoid hypoglycaemic symptoms increased from every $4-5 \mathrm{~h}$ to every $2 \mathrm{~h}$. Subsequently, overnight nutrient infusions were begun by nasogastric tube. ${ }^{11}$

During the $2 \mathrm{yr}$ before transplantation, multiple filling defects in her enlarged liver were seen on liver scans, with a dominant lesion in the right lobe. These were thought (and were later proved) to be slowly growing adenomas, but the possibility of a malignant change could not be ruled out. She had episodes of severe upper abdominal pain and liver swelling. In the year before transplantation, she had jaundice with a peak serum bilirubin concentration of $8 \mathrm{mg} / \mathrm{dl}(137 \mathrm{mmol} / \mathrm{l})$ and serum alkaline phosphatase exceeding $3000 \mathrm{IU}$, encephalopathy with blood ammonia levels around $350 \mu \mathrm{g} / \mathrm{dl}(206 \mu \mathrm{mol} / \mathrm{l})$, and persistent

Correspondence to: J. Jeffrey Malatack.

Correspondence should be addressed to J. J. M.. 
increases in serum transaminases. She was treated by protein restriction and intermittent intravenous alimentation. Her management was complicated by bacterial pseudomembranous colitis which was relieved by cholestyramine.

At the time of transplantation, she was small with normal vital signs, Tanner stage III pubertal changes, and the typical "potato face" of type I disease. She had bilateral right visual-field defects. The liver and spleen were palpable 10 and $6 \mathrm{~cm}$ below the right and left costal margins, respectively. There was no ascites. Orthotopic transplantation (liver replacement) was done with conventional techniques. ${ }^{12}$ The donor was a 14 -year-old boy of the same blood type. Cold ischaemia of the graft was $5 \mathrm{~h}$. Detachment of the portacaval shunt, closure of the resulting defect in the inferior vena cava, and anastomosis of the portal vein to the graft portal vein were not difficult. Biliary reconstruction was with an end-to-end duct anastomosis over a T-tube stent. The T-tube was clamped at $4 \mathrm{wk}$ and removed at $7 \mathrm{wk}$.

Postoperatively, a small bile leak and right subphrenic haematoma necessitated a minor drainage procedure. Immunosuppression was with cyclosporin and prednisone. ${ }^{8}$ After $5 \mathrm{wk}$ she was discharged on daily doses of $12 \mathrm{mg} / \mathrm{kg}$ cyclosporin and $15 \mathrm{mg}$ prednisone. There has been no evidence of rejection. After $1 \mathrm{yr}$, the daily cyclosporin dose is $9 \mathrm{mg} / \mathrm{kg}$ and prednisone has been reduced to $5 \mathrm{mg} /$ day.

\section{Results}

The histopathological findings in the native liver, which weighed $3400 \mathrm{~g}$, were consistent with type I glycogen storage disease. There were multiple hepatic adenomas. Biochemical studies of samples quick-frozen at $-70^{\circ} \mathrm{C}$ and stored on dry ice were done by Dr Barbara Illingworth Brown, Washington University, St Louis. The findings, including absence of glucose-6-phosphatase activity, were typical of type I glycogen storage disease (table). The glycogen concentration in the liver was $8.7 \%$.

Metabolic investigations were done $6 \mathrm{wk}$ postoperatively. The oral glucose tolerance test was normal after transplantation, with no hypoglycaemia at $3 \mathrm{~h}$-in contrast to the grossly aberrant findings at age $8 \mathrm{yr}$, just before the portacaval shunt (fig. 1). At age $8 \mathrm{yr}$, fasting for a brief period caused hypoglycaemia, whereas after transplantation, euglycaemia was maintained through a full day of fasting (fig. 2). Postoperatively, in either the fasting or the postprandial state, intramuscular injection of glucagon caused plasma glucose increments greater than $100 \%$ (fig. 3).

Standard liver function tests have been normal for $1 \mathrm{yr}$. Serum or plasma concentrations of lactates, lipids, and uric acid have been normal. The patient's lifestyle has been transformed. She eats three meals a day. For the first time in her life, she can participate in the educational and social overnight activities that are part of normal teenage development.

\section{Discussion}

Type I glycogen storage disease was the first inborn error of metabolism to be classified on the basis of deficiency of a specific enzyme, glucose-6-phosphatase. ${ }^{13}$ This enzyme is found in the liver, kidneys, and intestine. ${ }^{14}$ Deficiency of glucose-6-phosphatase activity precludes normal breakdown of glycogen to glucose and inhibits gluconeogenesis. The consequent metabolic disturbances include growth retardation, acidosis, lactic acidaemia,

hyperlipidaemia, and hyperuricaemia, ${ }^{15}$ Effective treatment for the disease has been developed only within the past two decades, and our patient has participated in each step of this therapeutic evolution. The first step was the demonstration that portal-systemic diversion ameliorated all of the disease manifestations except hypoglycaemia. ${ }^{10,16}$ Folkman et $\mathrm{al}^{17}$ showed that the same benefits could be achieved acutely by continuous parenteral 
alimentation. In an extension of this observation, Greene et al ${ }^{11}$ reported such good palliation, including control of hypoglycaemia, with round-the-clock enteral alimentation that this has become the treatment of choice. The overnight feedings have usually been by gastric tube.

Liver transplantation is a more specific option, but one which has been too dangerous to consider except for life-threatening complications such as those in our patient. However, the criteria for candidacy for this procedure will probably become less restrictive in view of the improved results with liver replacement that are being reported ${ }^{8}$ Although liver transplantation does not provide glucose-6-phosphatase directly for the kidneys or intestine, there has been no evidence of incompleteness of metabolic correction by the normally functioning transplanted liver.

\section{Acknowledgments}

This work was supported by research grants from the Veterans Administration; by project grant AM 29961 from the National Institutes of Health; and by grant RR 00084 from the General Clinical Research Centers Program of the Division of Research Resources, National Institutes d Health.

\section{Addendum}

About $1 \mathrm{yr}$ after transplantation, the patient had an episode of melaena. Oesophageal varices were the site of the haemorrhage. Superior mesenteric artery angiography and transhepatic portography revealed extrahepatic portal vein thrombosis. Excellent collateral filling of the intrahepatic portal vein and its branches was seen, indicating that the homograft still had good hepatopetal splanchnic flow. Sclerotherapy controlled the bleeding and liver functions and carbohydrate metabolism continue normal.

\section{REFERENCES}

1. Starzl TE, Marchioro TL, Rowlands DT Jr, Kirkpatrick CH, Wilson WEC, Rifkind D, Waddell WR. Immunosuppression after experimental and clinical homotransplantation of the liver. Ann Surg 1964:411-439. [PubMed: 14206848]

2. Merrill DA, Kirkpatrick CH, Wilson WEC, Riley CM. Change in serum haptoglobin type following human liver transplantation. Proc Soc Exp Biol Med 1964;116:748-751. [PubMed: 14194652]

3. Kashiwagi N, Groth CG, Starzl TE. Changes in serum haptoglobin and group specific component after orthotopic liver homotransplantation in humans. Proc Soc Exp Biol Med 1968;128:247-250. [PubMed: 4172932]

4. Kashiwagi, N. Special immunochemical studies. In: Starzl, TE., editor. Experience in hepatic transplantation. Philadelphia: W B Saunders; 1969. p. 394-407.

5. Alper CA, Johnson AM, Birtch AG, Moore FD. Human C'3: Evidence for the liver as the primary site of synthesis. Science 1969;163:286-288. [PubMed: 4883617]

6. Alper, Ca; Raum, D.; Awdeh, Z.; Petersen, BH.; Taylor, PD.; Starzl, TE. Studies of hepatic synthesis in vivo of plasma proteins, including orosomucoid, transferring, alpha-1-antitrysin, C8, and Factor B. Clin Immunol Immunopathol 1980;16:84-89. [PubMed: 6769626]

7. Raum D, Marcus D, Alper CA, Levey R, Taylor PD, Starzl TE. Synthesis of human plasminogen by the liver. Science 1980;208:1036-1037. [PubMed: 6990488]

8. Srarzl TE, Iwatsuki S, Van Thiel DH, Gartner JC, Zitelli BJ, Malatack JJ, Schade RR, Shaw BW Jr, Hakala TR, Rosenthal JT, Porter KA. Evolution of liver transplantation. Hepatology 1982;2:614636. [PubMed: 6749635]

9. Zitelli BJ, Malatack JJ, Gartner JC, Shaw BW Jr, Iwatsuki S, Starzl TE. Orthotopic liver transplantation in children with hepatic-based metabolic disease. Transplant Proc. (in press). 
10. Starzl TE, Putnam CW, Porter KA, Halgrimson CG, Corman J, Brown BI, Gorlin RW, Rodgerson DO, Greene HL. Portal diversion for the treatment of glycogen storage disease in humans. Ann Surg 1973;178:525-539. [PubMed: 4517839]

11. Greene HL, Slonim AE, Neil O, Burr IM. Continuous nocturnal intragastric feeding for management of type I glycogen storage disease. N Engl J Med 1976;294:423-425. [PubMed: 813144]

12. Starzl, TE. (with the assistance of Putnam CW). Experience in hepatic transplantation. Philadelphia: W B Saunders; 1969. p. 1-553.

13. Cori GT, Cori CF. Glucose-6-phosphatase in the liver in glycogen storage disease. J Biol Chem 1952;199:661-667. [PubMed: 13022673]

14. Nordlie, RC. Glucose-6-phosphatase, hydrolytic and synthetic activities. In: Boyer, PD., editor. The enzymes. New York: Academic Press; 1971. p. 543-610.

15. Greene HL, Slonim AE, Burr IM. Type I glycogen storage disease: a metabolic basis for advances in treatment. Adv Pediatr 1979;26:63-92. [PubMed: 120680]

16. Starzl TE, Marekioso TL, Sexton AW, Illingworth E, Waddell WB, Fares TD, Herrmann TJ. The effect of portocaval transposition on carbohydrate metabolism: Experimental and clinical observations. Surgery 1965;57:687-697. [PubMed: 14295780]

17. Folkman J, Philippart A, Tze WJ, Crigler J Jr. Portacaval shunt for glycogen storage disease: value of prolonged intravenous hyperalimentation before surgery. Surgery 1972;72:306-314. [PubMed: 4626293] 


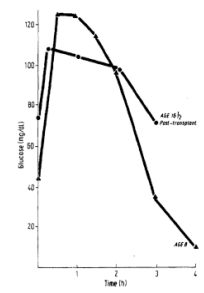

Fig. 1.

Oral glucose tolerance tat at age $8 \mathrm{yr}$ (before portacaval shunt) and $6 \mathrm{wk}$ after transplantation. 


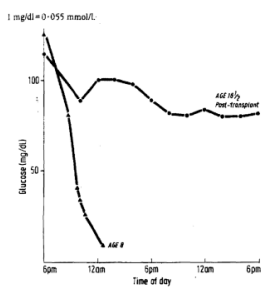

Fig. 2.

Response of blood glucose concentrations during fasting at age $8 \mathrm{yr}$ (before portacaval shunt), and 6 wk after liver transplantation. 


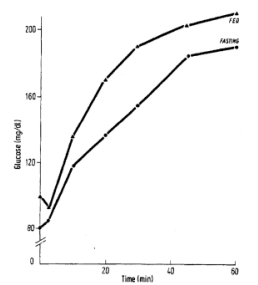

Fig. 3.

Glucose response to $1 \mathrm{mg}$ intramuscular glucagon in fasting and fed stare, 6 wk after liver transplantation. 


\section{Table}

LIVER ENZYME ACTIVITY OF EXCISED LIVER*

\begin{tabular}{l|c|c}
\hline Enzyme & $\begin{array}{c}\text { Patient } \\
(\mu \mathrm{mol} / \mathbf{m i n} / \mathbf{g} \text { liver })\end{array}$ & $\begin{array}{c}\text { Controls } \\
(\boldsymbol{\mu} \mathbf{m o l} / \mathbf{m i n} / \mathbf{g} \text { liver })\end{array}$ \\
\hline Glucose-6-phosphatasc & 0.08 & $3.7-14.4$ \\
Debranching enzyme & 0.58 & $0.25-0.75$ \\
Phosphorylase & 18.5 & $12.6-32.4$ \\
Fructose diphosphatase & 9.1 & $4.2-15.5$ \\
Lysomal $\alpha^{- \text {glucosidase }}$ & 2.32 & $0.63-2.85$ \\
\hline
\end{tabular}

* Analyses by Dr Barbara Illingworth Brown. The liver specimen contained $8.7 \%$ glycogen (normal<5\%). Control patients had liver biopsies because of metabolic disorders, hepatomegaly, or failure to thrive. The control ranges include at least 10 different samples. 